\title{
PROTECTION OF THE SEA REGION FROM OIL POLLUTION BY TANKER SHIP
}

\author{
Elly Kristiani Purwendah \\ Fakultas Hukum Universitas Wijayakusuma Purwokerto \\ Email elly_kristiani@yahoo.co.id
}

\begin{abstract}
In the context of national law, Law Number 32 Year 2009 concerning Environmental Protection and Management (UUPPLH) provides an understanding of the environment as a unitary space with all objects, forces, and living things, including humans and their behavior, which affect nature itself, continuity of life, and the welfare of humans and other living things. Environmental protection has general principles, namely: Sovereignty over natural resources and the responsibility not to cause damage to the environment of other states or areas beyond national jurisdiction; Principle of preventive action; Cooperation; Sustainable development. Specifically the mandate of the 1945 Constitution is spelled out in the weighing section of Law Number 32 of 2009 concerning Protection of Environmental Management (UUPPLH) which states that a good and healthy environment is the human right of every Indonesian citizen as mandated in Article 28H of the Law 1945 Constitution of the Republic of Indonesia. This law states that environmental protection and management are systematic and integrated efforts undertaken to preserve environmental functions and prevent environmental pollution and / or damage which includes planning, utilization, control, maintenance, supervision and law enforcement.
\end{abstract}

Keywords: sea area, sea pollution, protection of environmental management.

\section{Introduction}

Indonesia's sea area which reaches an area of 3.11 million $\mathrm{km} 2$ has caused the potential of the marine sector (Siahaan, 2018) to become invaluable, especially from the marine natural resources sector. The potential of marine wealth becomes so important as prioritized by Indonesia in the concept of green economy and blue economy that leads to sustainable development as stated by the President of Indonesia when giving his remarks at the Rio +20 Conference
(United Nations Conference on Suistanable Development) in Rio de Jeneiro, Brazil in June 20-22, 2012 (Lilley, 1999).

The marine environment is part of a country's economy (Gore, 1995). With a coastline of around 95,181 km, Indonesian waters have high potential. The measure is second only to Canada as the country which has the second longest coastline in the world. The economic value of the sea is estimated at US \$ 3 trillion - US \$ 5 trillion or equivalent to $\mathrm{Rp}$. 36,000 
trillion - Rp. 60,000 trillion per year. This figure does not include other potential derived from the wealth of biotechnology, marine tourism and the development of sea transportation. Indonesia's great maritime potential is captured as one of the leading mission and vision in the current Jokowi's presidential administration. In addition, the great economic and ecological potential that is stored as a maritime country, the potential for natural damage that can be caused by excessive exploration that can threaten the sustainability of development should also receive attention. For this reason, the government is currently pushing for a maritime economic policy with a blue economic model. Basically the blue economy combines economic development and environmental preservation.

Natural resources are used as efficiently as possible so that they are minimal / without waste. Indonesia has direct marine potential and wealth such as fisheries (pelagic and demersal fish, shrimp, drought, seaweed). The potential of this direct marketed product (market) continues to be an ever-increasing foreign exchange earner. On the other hand, the indirect potential of non-goods (non-market) marine tourism still needs to be developed, as well as the potential for renewable energy (including ocean currents, tides, ocean waves, Ocean Thermal Energy Convertion), minerals on the seabed, oil and gas earth, shipping, maritime industry, and marine services, are still potential to be developed. It is estimated that the potential reaches US $\$ 171$ billion per year, in detail can be stated as follows: Fisheries: US \$ 32,000,000,000 / year (IPB, 1997), Coastal areas: US \$ $56,000,000,000$ per year (ADB 1997), Biotechnology : US \$ 40,000,000,000 per year (PKSPL-IPB, 1997), Maritime Tourism: US \$2,000,000,000 per year (DEPBUDPAR, 2000), Petroleum: US \$ $21,000,000,000$ per year (ESDM 1999) and sea Transportation: US \$20,000 $.000,000$ per year (http://webcache.googleusercontent. com).

Considering the very strategic role of the sea because some people rely on the sea as their livelihood and life, the sea needs to get the main attention in law enforcement, especially from the effects of damage to the ecosystem due to pollution. Sources of marine pollution can come from: (1) pollution caused or originating from ships; (2) pollution originating from oil drilling installations; (3) sources of ground pollution; and (4) air pollution (Atmadja, 1992). The problem of oil pollution due to ship accident (tanker) in Indonesia needs to get serious attention regarding the right to sue (ius standi), evidence related to scientific verification to explain causal relationships, the application of the principle of compensation, the scope and extent of environmental issues to determine the amount of compensation, and environmental recovery criteria related to the formal truth system adopted in the civil compensation claim system (Triatmodjo, 2001). 
During the period of 2011-2015 there were 4 (four) oil pollution in the Cilacap sea. In 2011 there were two cases of pollution in July and September by the TT Super Tanker. Arenza XXVII and MT Ships. Medelin Atlas Belawan IMO 8717245, and in April 2012 MV. Indo Baruna V pollutes the marine environment of Cilacap. Finally in 2015 in May 2015 MT. Martha Petrol. The claim for compensation for oil pollution by oil tankers in the Cilacap sea was carried out by fishermen to PT. Pertamina through direct claims. Compensation calculation is calculated in the amount of direct loss of fishermen who cannot go to sea during pollution, multiplied by the number of fishermen registered as members of the All Indonesian Fishermen Association (HNSI). The All Indonesian Fishermen Association (HNSI) of Cilacap Regency requested compensation of $\mathrm{Rp} 40.7$ billion from PT Pertamina RU IV Cilacap due to oil leakage (Suara Merdeka, May 29, 2015).

Protection of the environment at sea and the demand for compensation for sea pollution directly by fishermen without the participation of the state is not in accordance with state obligations as stipulated in the constitutional basis of the 1945 Constitution, Article 33 Paragraph 3 which states that, "the earth and water and natural resources contained therein are controlled by the state and used for the greatest prosperity of the people ". Oil pollution in the Cilacap Sea leaves many problems, therefore this study seeks to examine the problem of Protection of Marine Areas From Oil Pollution by Tanker.

\section{Discussion}

\section{Definition of Sea Pollution}

Marine pollution according to GESAMP (Group of Experts on the Scientific Aspect of Marine Environmental Protection) is understood as: Pollution means the introduction by man, directly or indirectly, of substances or energy into the marine environment (including estuaries) resulting in such deleterious effects as harm to living resources, hazards to human health, Hindrance to marine activities including fishing, impairment of quality for use of sea water and reduction of amenities (IMO, 1993).

Sea pollution is defined by experts who are members of bodies under the United Nations as: Introduction by man, directly or indirectly, of substance or energy into the marine environment (including) resulting in such deleterious effects as harm to living resources, hazardous human health, hindrance to marine activities including fishing, impairment quality for use of sea water and reduction of amenities (Melda;2007).

The United States National Oceanic and Atmospheric Administration (NOAA) in its report at the Congress on ocean dumping said, "The unfavorable alteration of the marine environment ... thought directly or indirect effect of changes in energy patterns, traditions and 
distribution, abundance, and quality of organisms "(Smith, 2005).

The OECD defines sea pollution as something that is caused by humans whether intentional or not, which has an effect in the form of environmental damage or threat to human health and everything that can inhibit marine activities including fishery activities, declining sea water quality and disrupting other uses of the environment . Another definition, which is internationally recognized, is contained in Article 1 (4) of UNCLOS which states that: Pollution of the marine or directly, of substances or energy into the marine environment, including estuaries, which results or is likely to result in such deleterious effects as harm to living resources and marine life, hazards to human healts hindrance, to marine activities, including fishing and other legitimate uses of the sea, impairment of quality for uses of the sea, impairment of quality for use of the sea water and reduction of amenitie.

Two important factors in marine pollution, the first action carried out by humans (introduction by men) both intentional and unintentional, second is the human action caused a result in the form of damage to the environment (deleterius effect). Furthermore Komar Kantatmadja is of the opinion that sea pollution is the occurrence of changes in the marine environment that occur as a result of the direct or indirect inclusion of humans in materials or energy into the marine environment which results in such a bad effect that is a loss for biological wealth, a danger to health humans, disturbance to activities at sea including fisheries, the use of reasonable sea water, deterioration of sea quality and declining quality of residential and recreational places (Kusumaatmadja, 1977).

\section{Marine Pollution Categories}

Marine pollutants can be divided into six main categories, as follows:

1) Marine Pollution caused via the atmosphere by land-based activities Scientific evidence shows the existence of three main causes of marine pollution in this first class, namely: The use of various kinds of "synthethic chemical" in particular "Chlorinated hydrocarbons" for agriculture; The release of heavy metals ("heavy metal") such as mercury due industrial or other processes; Atmospheric impurity by the oil hydrocarbons produced by the use of petroleum to produce energy;

2) The disposal of domestic and industrial wastes. Pollution caused by the drainage of domestic or industrial waste from the coast, either through river "sewage outlets" or due to "dumping".

3) Ship-borne Pollutants. This type of pollution can consist of various forms of ships and cargo. The main causes are oil spills at sea, which can be distinguished due to ship activities such as disposal of ballast water or due to ship accident at sea, especially 
if the accident involves a tanker.

4)

Pollution from offshore mineral production Mining activities on the seabed, especially if there is a leak at the mining installation and waste disposal that does not meet specified requirements.

The Principle of Absolute Responsibility in Environmental Pollution

The principle of responsibility in environmental resolution, especially pollution, uses the principle of absolute responsibility, namely strict liability and absolute liability. Strict liability is a direct and immediate responsibility, a responsibility that is conditional on limiting the amount of compensation payments determined in advance in marine pollution in a direct and immediate manner. Absolute liability is an unconditional absolute responsibility (in full and in full in compensation payments). The stipulation of this principle in a country's laws and regulations is often caused by evolution in the international world, especially with the development of environmental law.

In 1978 the Indonesian government ratified the 1969 Civil Liability Convention and the 1971 Funds Convention in national law through Presidential Decree No. 18 of 1978 concerning Ratification of the 1969 CLC and Presidential Decree No. 19 of 1978 concerning Ratification of the Convention for the Prevention of Pollution from ships 1973 along with the Protocol of 1978 Relating to the International Convention for the Prevention of Pollution from the Ship 1973. With the ratification of the 1969 CLC the principle of strict liability began to be recognized in the Indonesian legal system, especially in the sphere of environmental law. This concept is understood as a type of activity that can be classified as extra hazardous or ultra hazardous or abnormally dangerous required to bear all losses incurred even though the person concerned has acted with extreme care (utmost care) to prevent all hazards and losses, even though the loss arises without intent (Siahaan, 2004).

In strict liability there is a defendant's obligation to assume responsibility for losses that are not related to his mistakes. The defendant's obligation to assume responsibility for this loss arises directly and immediately, once there is a fact that there has indeed been an event that caused the loss to occur. The principle of strict liability arises from the awareness of the community that for every act carried out either by individuals or groups, then the person or group will not be able to escape from responsibility for any losses caused by the act. This principle is always associated with compensation (Posner, 1986).

The concept of ultra hazardous, tort law imposes strict liability on activities that involve a high degree of danger that cannot be prevented by those who have acted cautiously or those who 
may be victims. The principle of strict liability has encouraged those who carry out activities that are classified as extra hazardous to make several alternatives that can reduce the degree of danger. The Injurer will take preventative measures at the optimal level because if he takes precautions below the optimal level there will be a total accident cost to be borne.

John D. Blackburn, Elliot I. Klayman and Martin H. Malin by referring to Article 520, the Restatement of the Law of Torts in America states that, to determine whether an activity is an abnormally dangerous activity so that it can be subject to strict liability there are several factors that can be used as determinants are (Priyatno, 2010):

1. The capacity involves a high degree of some harm to the person, land or chattels of others;

2. The harm which may result from it is likely to be great;

3. The risk cannot be eliminated by the exercise of reasonable care;

4. The activity is not a matter of a common usage;

5. The activity is in appropriate to the place where it is carried on;

6. The value of activity to the community.

In strict liability, a person is responsible whenever a loss arises. This explains the situation that:

1. The victims were released from a heavy burden to prove the existence of a causal relationship between the loss and the actions of the individual defendant;
2. The "potential polluter" will pay attention to both the level of caution (level of care), and level of activity (level of activity).

These two things are the advantages of strict liability from the concept of error. Because of its strict and hardiness, strict liability cannot be imposed on all activities. According to L.B. Curson's principle of strict liability is based on the following reasons:

1. It is essential to guarantee certain important regulations are required for social welfare;

2. Proving the existence of mens rea will be very difficult for violations related to social welfare;

3. The high level of social danger caused by the act in question.

Compensation in strict liability is usually associated with a ceiling or ceiling system (the maximum limit of responsibility). The responsible party is only charged to a certain extent. Indonesia adheres to the ceiling or ceiling in strict liability because in the explanation of Article 35 paragraph (1) of Law Number 23 of 1997 concerning Environmental Management (UUPLH) as well as in the explanation of Article 88 of Law Number 32 of 2009 concerning Environmental Protection and Management (UUPPLH) explained that the amount of compensation that can be charged to environmental pollutants or destroyers can be determined to a certain extent. Definition of certain 
limits according to the applicable laws and regulations, insurance obligations for businesses and / or activities concerned / environmental funds available.

\section{Principles of International Environmental Protection}

The definition of environmental law is related to two aspects, the first is related to the scope of the legal subject and its institutional competence; second, related to responsibility for environmental damage. The 1972 Stockholm Declaration (Melda; 2007), in Principle 2 states that the so-called natural resources on earth are "air, water, soil, flora, fauna and natural ecosystems". Meanwhile, European Community law agrees on the environment as the relationship between living things and water, air, soil and all biological forms. UNCLOS, as the main source of international marine law, includes rare and fragile ecosystems and habitats as a means of protecting the marine environment. In the context of national law, Law Number 32 Year 2009 concerning Environmental Protection and Management (UUPPLH) provides an understanding of the environment as a unitary space with all objects, forces, and living things, including humans and their behavior, which affect nature itself, continuity of life, and the welfare of humans and other living things. Environmental protection has general principles, namely:Sovereignity over natural resources and the responsibility not to cause damage to the environment of other states or to areas beyond national jurisdiction (Sands, 2003);

a. Principle of preventive action

b. Cooperation

c. Sustainable development The principle of sustainable has several aspects, namely:

1) The need to take into consideration the needs of present and future generation;

2) The acceptance on environment protection grounds, of limit placed upon the use and exploitation of natural resources;

3) The role of equitable principles in the allocation of rights and obligation;

The principle to be used for allocating costs of pollution prevention and control measures to encourage rational use of scarce environmental resource and to avoid distortions in international trade and investment is so called polluter pays principle. That principle means that that polluter should bear the expenses of caring out the above mentioned measures decided by the public authorities to ensure that the environment is in a acceptable states. In other world the cost of these measures should be reflected in the cost of goods and services which cause pollution in production and/or consumption. Such measures should not be accompanied by subsidies that would create significant distortions in international trade and investment.
d. Precutionary Principle
Dalam Prinsip ke-15 Deklarasi 
Rio dinyatakan bahwa : where there are threats of serious or irreversible damage, lack of full scientific certainly shall not be used as areas on for post poning cost effective measures to prevent environmental degradation". That principle means that polluter should bear the expenses of caring out the above mentioned measures decided by the public authorities to ensure that the environment is in a acceptable states. In other world the cost of these measures should be reflected in the cost of goods and services which cause pollution in production and/or consumption. Such measures should not be accompanied by subsidies that would create significant distortions in international trade and investment.

Legal Regulations Regulating the Importance of Protecting the Marine Environment from Oil Pollution by Tanker

National economic development as mandated by the 1945 Constitution of the Republic of Indonesia (UUD '45) is based on the principle of sustainable development and environmental insight. In addition, the deteriorating quality of the environment has threatened the survival of human life and other living creatures, so it is necessary to truly and consistently protect and manage the environment by all stakeholders.

Specifically the mandate of the 1945 Constitution is spelled out in the weighing section of Law Number 32 of 2009 concerning Protection of
Environmental Management (UUPPLH) which states that a good and healthy environment is the human right of every Indonesian citizen as mandated in Article $28 \mathrm{H}$ of the Law 1945 Constitution of the Republic of Indonesia. This law states that environmental protection and management are systematic and integrated efforts undertaken to preserve environmental functions and prevent environmental pollution and / or damage which includes planning, utilization, control, maintenance, supervision and law enforcement.

Environmental protection and management in Indonesia as referred to in Article 2 of the UUPPLH is based on principles; state responsibility, sustainability and sustainability, harmony and balance, cohesiveness, benefits, prudence, justice, ecoregion, biodiversity, paying polluter, participatory, local wisdom, good governance and regional autonomy. Environmental protection and management includes; planning, utilization, control, maintenance, supervision and law enforcement. Environmental control in this case is intended to include prevention, mitigation and recovery carried out by the government, regional government and those responsible for businesses and / or activities in accordance with their respective authorities, roles and responsibilities.

An interesting thing in the UUPPLH is the existence of Article 66 which states that, every person who fights for the 
right to a good and healthy environment cannot be prosecuted criminal or civilly sued. This article regulates the participation of the public in obtaining legal protection so that they cannot be prosecuted for criminal or civil litigation when the community participates in fighting for the right to a good and healthy environment. The concept of Article 66 is known as the Anti Strategic Lawsuit Against Public Participation (Anti SLAPP). When the SLAPP concept was first published, George W. Pring and Penelope Canan as the inventors of this concept divided SLAPP into several fields including real estate development, taxation, the environment, and others. Specifically for SLAPP that occurs in the environmental field, Pring and Canan popularized the term Eco-SLAPP (SLAPPs; Getting Sued for Speaking Out, 1996). In the elucidation of Article 66 it is stated that this provision is intended to protect victims and / or reporters who use legal methods due to environmental pollution and / or damage. This protection is intended to prevent retaliation from being reported through criminal punishment and / or civil lawsuits while taking into account the independence of the judiciary.

The term marine as understood through Law Number 32 of 2014 Concerning Maritime Affairs, Supplement to the State Gazette of the Republic of Indonesia Number 5605 (Maritime Law), is stated as, "... matters relating to the sea and / or activities in the sea area which includes the seabed and the land beneath, the water column and sea level, including coastal areas and small islands. The Maritime Law further states that the protection of the marine environment is a systematic and integrated effort undertaken to conserve marine resources and prevent pollution and / or damage to the environment at sea which includes marine conservation, control of marine pollution, control of marine disasters, prevention and prevention of pollution, and damage and disaster.

In this Maritime Law the protection of the marine environment is the responsibility of the government through the control of marine pollution and the prevention and control of pollution and disaster pollution. One of the ways in which marine disasters is understood is environmental pollution in addition to natural phenomena and global warming. Marine disasters caused by environmental pollution can be in the form of oil pollution. More interestingly, the Maritime Law discusses marine pollution in a separate article which, among other things, states that, in anticipating sea pollution, the government establishes policies to mitigate the effects of sea pollution. The policy for overcoming the impact of marine pollution can be done through the development of national plans for emergency response to oil spills at sea, and the development of systems for controlling marine pollution and 
damage to marine ecosystems. In Article 55 Paragraph (1) it is said that the government and regional government are obliged to implement a system of prevention and control of pollution and damage to the marine environment. Furthermore, in Article 55 Paragraphs (1), (2) and (3) which state that, the government is responsible for protecting and preserving the marine environment, protecting and preserving the marine environment through prevention, reduction and control of the marine environment from any marine pollution and handling damage to the marine environment, and the government cooperating, both bilaterally, regionally and multilaterally in implementing prevention, mitigation and control.

The protection and preservation of the marine environment is carried out based on statutory provisions and international marine law. For marine governance and institutions, in Article 69 it is explained that, the government established a marine governance and institutional policy. The marine governance and institutional policy encompasses planning for the development of a legal and governance system as well as an effective and efficient planning, coordination, monitoring and evaluation of marine development. In developing marine governance and institutional policies, the government conducts sea law structuring in a national legal system through both the public and civil aspects by taking into account international law.

An interesting thing in the Maritime Law is the existence of a Chapter that regulates community participation, namely Chapter XI, Article 70 which states that the implementation of marine development is carried out by the government and regional government by involving community participation, community participation can be carried out by individuals, groups, professional organizations, business entities or other social organizations according to the principles of openness and partnership. Community participation in marine development is carried out through participation in; formulation of marine development policies, marine management, marine development and provide input in evaluation and supervision activities. Community participation can be done through participation in preserving cultural values and maritime insights and revitalizing customary law and local wisdom in the marine field, or protecting and promoting underwater cultural heritage through preservation, restoration and conservation efforts.

\section{Conclusion}

In the context of national law, Law Number 32 Year 2009 concerning Environmental Protection and Management (UUPPLH) provides an understanding of the environment as a unitary space with all objects, forces, and living things, including humans and their behavior, which affect nature 
itself, continuity of life, and the welfare of humans and other living things. Environmental protection has general principles, namely: Sovereignty over natural resources and the responsibility not to cause damage to the environment of other states or areas beyond national jurisdiction; Principle of preventive action; Cooperation; Sustainable development. Specifically the mandate of the 1945 Constitution is spelled out in the weighing section of Law Number 32 of 2009 concerning Protection of Environmental Management (UUPPLH) which states that a good and healthy environment is the human right of every Indonesian citizen as mandated in Article $28 \mathrm{H}$ of the Law 1945 Constitution of the Republic of Indonesia. This law states that environmental protection and management are systematic and integrated efforts undertaken to preserve environmental functions and prevent environmental pollution and / or damage which includes planning, utilization, control, maintenance, supervision and law enforcement. Environmental protection and management in Indonesia as referred to in Article 2 of the UUPPLH is based on principles; state responsibility, sustainability and sustainability, harmony and balance, cohesiveness, benefits, prudence, justice, ecoregion, biodiversity, paying polluter, participatory, local wisdom, good governance and regional autonomy. Environmental protection and management includes; planning, utilization, control, maintenance, supervision and law enforcement. Environmental control in this case is intended to include prevention, mitigation and recovery carried out by the government, regional government and those responsible for businesses and / or activities in accordance with their respective authorities, roles and responsibilities.

\section{Reference:}

Albert Gore, 1995, Marine Degradation from Land Based Activities: A Global Concern, Artikel dalam U.S. Department of States Dispatch, Vol. 6: No. 46.

Gayatri R. Lilley, 1999, Demokrasi Pengelolaan Sumber Daya Alam, Prosiding Lokakarya Reformasi Hukum di bidang Pengelolaan Sumber Daya Alam, Cetakan I, ICEL, Pustaka Pelajar Offset.

Hendry Roris P. Siahaan, 2018, Ini Data Baru Kewilayahan Laut Indonesia, Gatra.com 10 Agustus 2018, https://www.gatra.com/rub riknasional/337332-Ini-DataBaru-Kewilayahan-LautIndonesia.

IMO, 1993, Impact of Oil and Related Chemicals on the Marine Environment, IMO/FAO/UNESCO/WMO/IA EA/UN/UNEP Joint Group of Expert on the Scientific Aspect of Marine Pollution (GESAMP), London.

John Baylish, Steve Smith, 2005, The Globalization of World Politics (3rd ed), Oxford University 
Press, Oxford.

Mangku, D. G. S. (2010). Pelanggaran terhadap Hak Kekebalan Diplomatik (Studi Kasus Penyadapan Kedutaan Besar Republik Indonesia (KBRI) di Yangon Myanmar berdasarkan Konvensi Wina 1961). Perspektif, 15(3).

Mangku, D. G. S. (2011). Peluang dan tantangan ASEAN dalam penyelesaian sengketa Kuil Preah Vihear di perbatasan Kamboja dan Thailand. Pandecta: Research Law Journal, 6(2).

Mangku, D. G. S. (2012). Suatu Kajian Umum tentang Penyelesaian Sengketa Internasional Termasuk di Dalam Tubuh ASEAN. Perspektif, 17(3).

Marsudi Triatmodjo, 2001, Pengembangan Pengaturan Hukum dan Kelembagaan Pencemaran Laut dari Darat di Kawasan Asia Tenggara, Makalah dalam Hukum dan Lingkungan Hidup Indonesia: 75 Tahun Prof. Dr. Koesnadi Hardjasoemantri,

Perpustakaan Nasional : Katalog Dalam Terbitan (KDT) Erman Rajagukguk dan Ridwan Khairandy (Ed), Program Pasca Sarjana Fakultas Hukum Universitas Indonesia.

Marsudi Triatmodjo, 2001, Pengembangan Pengaturan Hukum dan Kelembagaan Pencemaraan Laut dari darat di Kawasan Asia Tenggara, dalam
Hukum dan Lingkungan Hidup di Indonesia, 75 Tahun Prof. R. Koesnadi Harjasoemantri, $S H$, $M L$ dikatakan bahwa definisi sesuai Gesamp diakomodir dalam The Montreal Guidelines on the Protection Environment Against Pollution from Land Based Sources (Montreal Guidelines 1985)

Media Keuangan, Transparansi Informasi Kebijakan Fiskal, 2015, Ekonomi Biru, Harapan Baru Konsep Pembangunan yang Ramah terhadap Alam Potensi menjadi Landasan Program dan Kebijakan di Sektor Maritim, Volume X, Nomor 91, April 2015.

Melda Kamil Ariadno, Hukum Internasional Hukum yang Hidup, 2007, Diadit Media, Jakarta.

Melda Kamil Ariadno, Hukum Internasional Hukum yang Hidup, 2007, Diadit Media, Jakarta.

Mochtar Kusuma Atmadja, 1992, Perlindungan dan Pelestarian Lingkungan Laut Dilihat dari Sudut Hukum Internasional, Regional dan Nasional, Sinar Grafika dan Pusat Studi Wawasan Nusantara, Jakarta.

Mochtar Kusumaatmadja, 1977, Pencemaran Laut dan Pengaturan Hukumnya, Universitas Padjajaran, Bandung.

Muladi dan Dwijda Priyatno, 2010, Pertanggungjawaban Pidana Korporasi, Kencana, Jakarta. 
N.H.T. Siahaan, 2004, Hukum Lingkungan dan Ekologi Pembangunan, Erlangga, Jakarta.

Philippe Sands, 2003, Principle of International Environmental Law, Second Edition, Cambridge University Press, Cambridge.

Pusat Pendidikan Kelautan dan Perikanan Badan Pengembangan SDM Kelautan dan Perikanan Kementrian Kelautan dan Perikanan, 2014, Blue Economy Goes to Campus, Kementrian Kelautan dan Perikanan.

Richard A. Posner, 1986, Economic Analysis of law, Little Brown \& Company, Canada.

SLAPPs; Getting Sued for Speaking Out, 1996, Temple University Press, Philadelpia.

Suara Merdeka, 29 Mei 2015 3:02 WIB, http:/ / berita.suaramerdeka.c om/smcetak/hnsi-tuntutganti-rugi-rp-407-miliar/, diunduh pada Sabtu, 5 Maret 2019, Pukul 13.00. WIB.

Yusni Ikhwan Siregar, Menggali Potensi Sumber Daya Laut Indonesia, Makalah disampaikan Pada Workshop Forum Rektor Indonesia USU, $6 \quad$ Maret 2015. http:/ / webcache.googleuserc ontent.com/search?q=cache: ZXX8DHbTGQgJ:usu.ac.id/p ublic/cont ent/files/USU\% 2520MAKAL AH\% 2520Prof\% 2520Yusni\%2 520Ikhwan.pdf $+\& \mathrm{~cd}=1 \& \mathrm{hl}=\mathrm{i}$ $\mathrm{d} \& \mathrm{ct}=\mathrm{clnk} \& \mathrm{gl}=\mathrm{id}$, Mangku, D. G. S. (2013). Kasus Pelanggaran Ham Etnis Rohingya: Dalam Perspektif ASEAN. Media Komunikasi FIS, 12(2).

Mangku, D. G. S., \& Itasari, E. R. (2015). Travel Warning in International Law Perspective. International Journal of Business, Economics and Law, 6(4).

Purwanto, H., \& Mangku, D. G. (2016). Legal Instrument of the Republic of Indonesia on Border Management Using the Perspective of Archipelagic State. International Journal of Business, Economics and Law, 11(4).

Purwendah, E., Mangku, D., \& Periani, A. (2019, May). Dispute Settlements of Oil Spills in the Sea Towards Sea Environment Pollution. In First International Conference on Progressive Civil Society (ICONPROCS 2019). Atlantis Press. 